\title{
The first observation of obligate saproxylic chafer larvae inside white stork Ciconia ciconia nest
}

\author{
Adam Zbyryt ${ }^{1} \cdot$ Andrzej Oleksa $^{2}$ (C)
}

Received: 29 August 2018 / Accepted: 13 November 2018 / Published online: 17 November 2018

(c) The Author(s) 2018

\begin{abstract}
The white stork Ciconia ciconia nest, with its impressive size of over $1.5 \mathrm{~m}$ in height, a diameter of over $1.5 \mathrm{~m}$ and weight exceeding a ton, belongs the largest and heaviest structures built by birds all over the world. This permanent construction which is made of long sticks laid in layers and the thick lining consisting of hay, straw, manure, rubbish and rags, could last for decades. During that time, it can be an attractive shelter and breeding site for many organisms, including small birds, mammals and arthropods. However, due to some methodological constraints, the role of such nests for the diversity of saproxylic insects has not been well recognized so far. Here we report the first observation of occurrence of larvae of obligate saproxylic marbled rose-chafer, Protaetia lugubris (Cetoniinae) inside the white stork nest. We further discuss that the interior of a long-term stork nest may be an alternative to interiors of tree hollows in which typically most chafer's larvae develop. Thus, white stork nest could provide supplementary habitat for saproxylic beetles of conservation interests.
\end{abstract}

Keywords Saproxylic beetles $\cdot$ Cetoniinae $\cdot$ Protaetia lugubris $\cdot$ Liocola marmorata $\cdot$ Alternative habitat $\cdot$ Large bird nest

The white stork Ciconia ciconia nest is one of the largest and heaviest structures built among birds all over the world. Many white stork nests are used for decades, and each year they are repaired and expanded, thanks to which they can reach an impressive size of over $1.5 \mathrm{~m}$ in height, a diameter of over $1.5 \mathrm{~m}$ and a huge weight exceeding a ton (Gotzman and Jabłoński 1972; Cramp and Simmons 1977; Creutz 1985). The stork's nest is made of dry and long sticks laid in layers, and the thick lining consists of hay, straw, manure, and sometimes also rubbish and rags (Cramp and Simmons 1977; Gotzman and Jabłoński 1972). For this reason, $C$. ciconia nests can be an attractive shelter and breeding site for many organisms, of which the most well-known are vertebrates, mainly birds (Indykiewicz 2006; Zbyryt et al. 2017). Other less numerous are small mammals such as the brown rats (Rattus norvegicus), striped field mouse Apodemus agrarius or red squirrel Sciurus vulgaris

Andrzej Oleksa

olek@ukw.edu.pl

1 The Polish Society for Birds Protection (PTOP), Ciepła 17, 15-471 Białystok, Poland

2 Institute of Experimental Biology, Kazimierz Wielki University, Powstańców Wielkopolskich 10, 85-090 Bydgoszcz, Poland
(Indykiewicz 2006, own observations). However, stork nests are also places of occurrence of numerous invertebrates. Earlier studies indicated that stork nests can be occupied by at least 34 species of mites (Błoszyk et al. 2005; Mammeria et al. 2014) as well as ants Formica sp. and wasps Vespa sp. (Heckenroth 1969), which, however, were not identified to the species level. In addition to being a shelter and breeding site for many animals, white stork nests are important seed banks for almost 100 species of plants (Czarnecka and Kitowski 2013).

On $21 / 03 / 2018$ in the village of Starczewice $\left(52^{\circ} 23^{\prime} 34.6^{\prime \prime} \mathrm{N} ; 22^{\circ} 36^{\prime} 11.8^{\prime \prime} \mathrm{E}\right)$ located in north-eastern Poland, work was carried out to relieve the nest of a white stork situated on a wooden pole. This action was aimed at reducing its weight and height in order to prevent the old structure from falling over. Its dimensions were: $90 \mathrm{~cm}$ in height and a diameter of $100 \mathrm{~cm}$, with the predictable weight of over $600 \mathrm{~kg}$ (own data). During the removal of successive layers of highly frozen nest material, in its central part composed of strongly decomposed and compacted severalyear-old lining, which also included numerous rags, three full-grown larvae (length of ca. $7 \mathrm{~cm}$ ) of marbled rose-chafer Protaetia lugubris (Herbst, 1786) were found. This species is better known as Liocola lugubris and has formerly been 
known as L. marmorata or P. marmorata (Fabricius, 1772) (Fig. 1).

Old stork nests due to their size may be specific hotspots with a large biodiversity for many organisms. In the case of some species, especially birds, this subject has been quite well recognized and it is known that the nests of these birds are a very important breeding site for sparrows Passer domesticus, tree sparrows P. montanus and starlings Sturnus vulgaris (Indykiewicz 2006; Zbyryt et al. 2017). However, the occurrence of insects in C. ciconia nests has not been the subject of thorough research so far, although there are reports on scarab larvae occurrence in other large birds' nests of similar design (Choi et al. 2018; Koshiyama et al. 2012). This is due to several reasons. Firstly, the search for scarab larvae is associated with the total or partial destruction of the nest, and these structures are occupied by birds for many years, and even for decades (Cramp and Simmons 1977). Secondly, due to its size and location on the roofs of buildings or power poles, it requires a good and considerable logistical preparation. The volume of the stork's nest ranges from 0.9 to $3.6 \mathrm{~m}^{3}$ and it weighs on average $349 \mathrm{~kg}$ (own data). This discovery was made during the protective measures to reduce the nest, to prevent it from collapsing of the old post on which it was located. Combining such activities with searching white stork nests for the occurrence of cariophages (i.e. saprophages feeding on rotting wood, Pawłowski 1961) or other saproxylic organisms may be a good idea to investigate how often such cases occur.

P. lugubris is described as threatened over most of its distributional range. In the European red list of saproxylic beetles (Nieto and Alexander 2010; Cálix et al. 2018), it is assessed as Least Concern (Mannerkoski et al. 2010). Adults of the marbled rose-chafer prefer to feed on sap flow on tree trunks and the juice and flesh of soft, ripe fruits. Similarly to all chafers (Scarabaeidae: Cetoniinae), P. lugubris has specialized to develop in decomposing cellulose-rich plant material during the larval stage (Tauzin 2006; Oleksa et al. 2006). Chafer larvae have the form of a grub and usually develop in decayed wood, particularly in the wood mould in living hollow trees. Special adaptations in the structure of the digestive tract (Pawłowski 1961) and symbiotic microorganisms (Hackstein and Stumm 1994; Jönsson et al. 2004) allow them to feed on this little digestible source of food.

The interior of a long-term white stork nest may be an alternative to interiors of tree hollow, especially in the case of lack or little availability of old-growth trees. However, it can be supposed that large bird nests may support only a limited number of species, mainly necrophagous and specialised saprophagous species, compared to tree hollows. The marbled rose-chafer due to its plasticity in the selection of sites for larval development (Oleksa et al. 2006) may be more often found in white stork nests than other cariophagous chafers. The scale of this phenomenon is currently unknown because as previously mentioned no systematic research on this subject has been conducted so far, and the described occurrence is the first report on this subject. It is all the more important and interesting that another species of the Scarabaeidae family inhabiting similar tree hollow habitats as $P$. lugubris is the hermit beetle Osmoderma eremita s.l., which is a near-threatened or vulnerable species in Poland (Oleksa 2009, 2012) and all over Europe (Ranius et al. 2005; Maurizi et al. 2017; Nieto and Alexander 2010). Many sites occupied by the hermit beetle are known from the northern part of Poland, where one of the largest density of breeding pairs of the white stork is also found (Zbyryt et al. 2014). Therefore, we recommend beginning research on the occurrence of Scarabaeidae in stork nests in that region.

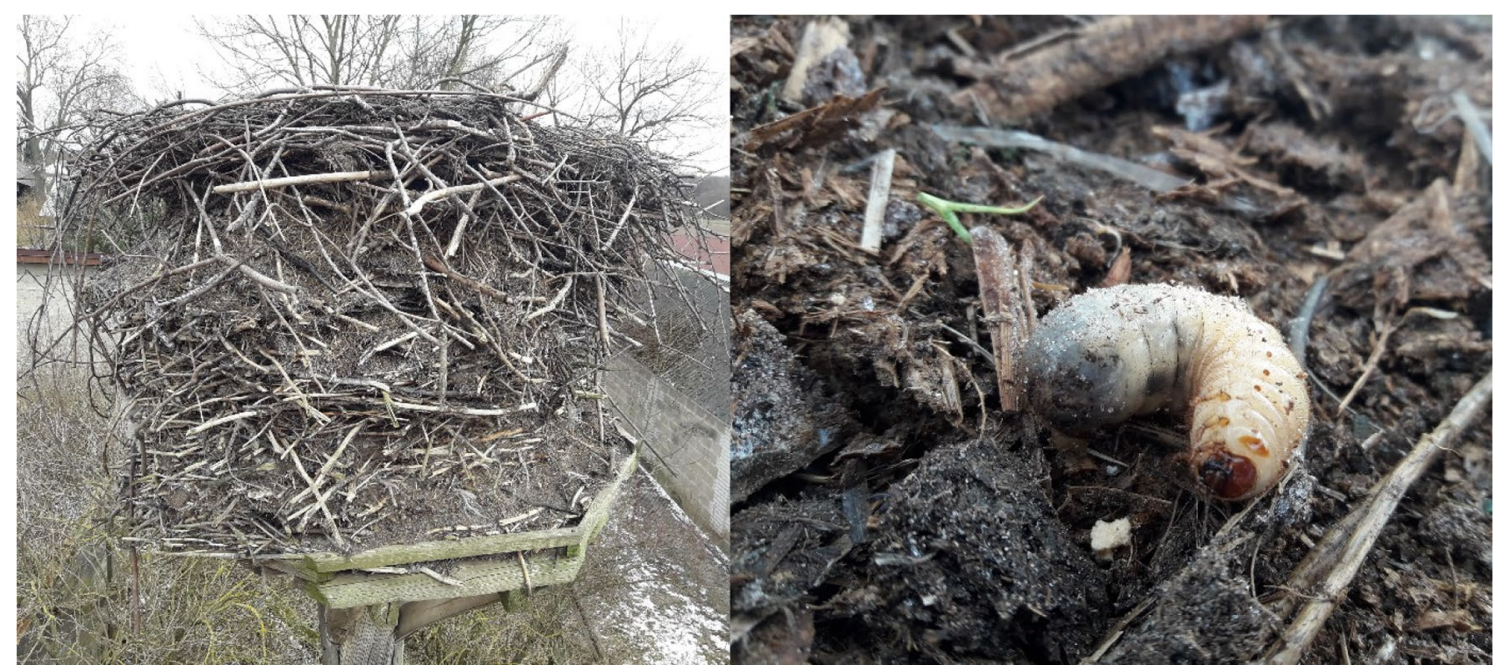

Fig. 1 White Stork nest in which Protaetia lugubris larvae were found 
Furthermore, our observation suggests that large birds' nests can be important although underinvestigated habitat of some insects of conservation importance. Hence, we strongly encourage research dealing with the role of birds' nests as structures that increase biodiversity.

Acknowledgements This work was financed by the LIFE financial instrument of the European Community and co-financed by the Vogelschutz-Komitee e.V. under the Project "Conservation of White Stork in the River Valleys of Eastern Poland" (LIFE15 NAT/PL/000728).

\section{Compliance with ethical standards}

Conflict of interest The authors declare that they have no conflict of interest.

Ethical approval This work was carried out in accordance with the Polish law (Article 52 of Nature Conservation Act) in consultation with the Regional Directorate for Environmental Protection in Bialystok.

Open Access This article is distributed under the terms of the Creative Commons Attribution 4.0 International License (http://creativeco mmons.org/licenses/by/4.0/), which permits unrestricted use, distribution, and reproduction in any medium, provided you give appropriate credit to the original author(s) and the source, provide a link to the Creative Commons license, and indicate if changes were made.

\section{References}

Błoszyk J, Gwiazdowicz DJ, Bajerlein DB, Halliday RB (2005) Nests of the white stork Ciconia ciconia (L.) as a habitat for mesostigmatic mites (Acari, Mesostigmata). Acta Parasitol 50:171-175

Cálix M, Alexander KNA, Nieto A, Dodelin B, Soldati F, Telnov D, Vazquez-Albalate X, Aleksandrowicz O, Audisio P, Istrate P, Jansson N, Legakis A, Liberto A, Makris C, Merkl O, Mugerwa Pettersson R, Schlaghamersky J, Bologna MA, Brustel H, Buse J, Novák V, Purchart L (2018) European red list of saproxylic beetles. IUCN, Brussels

Choi C-Y, Nam H-Y, Park C-R, Lee W-S (2018) Life cycle of Anthracophora rusticola (Coleoptera: Cetoniidae) from the commensal nests of Chinese Sparrowhawks (Accipiter soloensis). J Asia Pac Entomol 21:25-28. https://doi.org/10.1016/J.ASPEN.2017.09.015

Cramp S, Simmons KEL (eds) (1977) Handbook of the birds of Europe, the Middle East, and North Africa: the birds of the Western Palearctic. Oxford University Press, Oxford

Creutz G (1985) Der Weissstorch Ciconia ciconia. A. Ziemsen Verlag, Wittenberg Lutherstadt

Czarnecka J, Kitowski I (2013) The white stork as an engineering species and seed dispersal vector when nesting in Poland. Ann Bot Fennici 50:1-12

Gotzman J, Jabłoński B (1972) Gniazda naszych ptaków [Our bird's nests, in Polish]. PZWS, Warszawa

Hackstein JH, Stumm CK (1994) Methane production in terrestrial arthropods. Proc Natl Acad Sci USA 91:5441-5445

Heckenroth H (1969) Der Weißstorch-Bestand 1965 im westlichen Mittel-Europa. Vogelwarte 25:27-46

Indykiewicz P (2006) House sparrow Passer domesticus, Starling Sturnus vulgaris, tree sparrow Passer montanus and other residents of the white stork Ciconia ciconia. In: Tryjanowski P, Sparks TH,
Jerzak L (eds) The white stork in Poland: studies in biology, ecology and conservation. Bogucki Wydawnictwo Naukowe, Poznan, pp 225-235

Jönsson N, Méndez M, Ranius T (2004) Nutrient richness of wood mould in tree hollows with the Scarabaeid beetle Osmoderma eremita. Anim Biodivers Conserv 2:79-82

Koshiyama Y, Miyata R, Miyatake T (2012) Meat-eating enhances larval development of Anthracophora rusticola Burmeister (Coleoptera: Scarabaeidae), which breeds in bird nests. Entomol Sci 15:23-27. https://doi.org/10.1111/j.1479-8298.2011.00470.x

Mammeria AB, Bitam I, Boutellis A, Kernif T (2014) First account of arthropods in the nest of the white stork, Ciconia ciconia, in Algeria, including the flea Ctenocephalides felis. Bull la Soc Zool Fr 139:199-213

Mannerkoski I, Hyvärinen E, Campanaro A, Alexander K, Büche B, Dodelin B, Mason F, Pettersson R, Mico E, Méndez M (2010) Protaetia lugubris. The IUCN red list of threatened species 2010:e.T157932A5176205

Maurizi E, Campanaro A, Chiari S, Maura M, Mosconi F, Sabatelli S, Zauli A, Audisio P, Carpaneto GM (2017) Guidelines for the monitoring of Osmoderma eremita and closely related species. Nat Conserv 20:79-128. https://doi.org/10.3897/natureconservat ion. 20.12658

Nieto A, Alexander KNA (2010) European red list of saproxylic beetles, IUCN species programme, IUCN red list of threatened species-regional assessment. Publications Office of the European Union, Luxembourg. https://doi.org/10.2779/84561

Oleksa A (2009) Conservation and ecology of the hermit beetle Osmoderma eremita s.1. in Poland. In: Buse J, Alexander K, Ranius T, Assmann T (eds) Saproxylic beetles-their role and diversity in European woodland and tree habitats. Proceedings of the 5th symposium and workshop on the conservation of saproxylic beetles. Pensoft Series Faunistica, Issue 89, pp 177-188

Oleksa A (ed) (2012) Ochrona pachnicy w Polsce [Conservation of the hermit beetle in Poland-outline of action plan, in Polish]. Fundacja EkoRozwoju, Wrocław

Oleksa A, Ulrich W, Gawroński R (2006) Occurrence of the marbled rose-chafer (Protaetia lugubris Herbst, Coleoptera, Cetoniidae) in rural avenues in northern Poland. J Insect Conserv 10:241-247. https://doi.org/10.1007/s10841-005-4830-1

Pawłowski J (1961) Próchnojady blaszkorożne w biocenozie leśnej Polski [Lamellicorn cariophages in forest biocenoses of Poland, in Polish]. Ekologia Polska A 9:355-437

Ranius T, Aguado LLO, Antonsson K, Audisio P, Ballerio A, Carpaneto G, Chobot K, Gjurasin B, Hanssen O, Huijbregts H, Lakatos F, Martin O, Neculiseanu Z, Nikitsky NB, Paill W, Pirnat A, Rizun V, Ruicanescu A, Stegner J, Süda I, Szwalko P, Tamutis V, Telnov D, Tsinkevich V, Versteirt V, Vignon V, Vögeli M, Zach P, Gjurašin B, Hanssen O, Huijbregts H, Lakatos F, Martin O, Neculiseanu Z, Nikitsky NB, Paill W, Pirnat A, Rizun V, Ruicanescu A, Stegner J, Süda I, Szwałko P, Tamutis V, Telnov D, Tsinkevich V, Versteirt V, Vignon V, Vögeli M, Zach P (2005) Osmoderma eremita (Coleoptera, Scarabaeidae, Cetoniinae) in Europe. Anim Biodivers Conserv 28:1-44

Tauzin P (2006) Ethologie et chorologie de Protaetia (Liocola) lugubris en France. Cetoniimania 1-2:4-38

Zbyryt A, Menderski S, Niedźwiecki S, Kalski R, Zub K (2014) Populacja lęgowa bociana białego Ciconia ciconia w Ostoi Warmińskiej [White Stork Ciconia ciconia breeding population in Warmińska Refuge (Natura 2000 Special Protection Area), in Polish]. Ornis Polonica 55:240-256

Zbyryt A, Jakubas D, Tobółka M (2017) Factors determining presence of passerines breeding within White Stork Ciconia ciconia nests. Sci Nat 104:71. https://doi.org/10.1007/s00114-017-1492-2 